\title{
PENINGKATAN PERILAKU MORAL PADAANAK USIA 5-6 TAHUN MELALUI PENGGUNAAN METODE BERCERITA
}

\author{
Aidha Artha Novayanty \\ PG-PAUD FIP Universitas Negeri Jakarta \\ aidhaartha27@gmail.com
}

\begin{abstract}
$A B S P T R A C T$
The objective of this research was to explain the process and learning outcomes of using storytelling which can improved moral behavior in children aged 5-6 years at BKB PAUD Tunas Beringin with child research subjects amount 10 people. The moral behavior indicators studied are polite, caring, honest, obeying the rules and responsibilities. The method used in this research is Action Research, using Kemmis \& McTaggart. The research findings quantitatively, describe the percentage of increase of $22 \%$ with the average class end result in the first cycle of $59 \%$ from $37 \%$ in preresearch, whereas in cycle II, the percentage increase of $26 \%$ with the average class end result on Cycle II by $85 \%$. The total grade increase from pre-end to cycle II was $48 \%$. This has the meaning that there has been an increase in moral behavior of children from pre-research to the end of cycle II. Based on this, it can be concluded that in the early childhood learning process should apply appropriate methods and media, providing motivation and real examples that are reflected in everyday life.
\end{abstract}

Keywords: Moral behavior, storytelling, action research

\section{ABSTRAK}

Tujuan penelitian ini adalah untuk mendeskripsikan proses dan hasil pembelajaran menggunakan metode bercerita untuk dapat meningkatkan perilaku moral anak usia 56 tahun di BKB PAUD Tunas Beringin dengan subjek penelitian berjumlah 10 anak. Indikator perilaku moral yang diteliti adalah sopan santun, kepedulian, kejujuran, mematuhi aturan dan tanggungjawab. Metode yang digunakan dalam penelitian ini adalah Penelitian Tindakan Kelas (PTK) dengan menggunakan model Kemmis \& McTaggart. Temuan penelitian secara kuantitatif, menggambarkan persentase kenaikan sebesar 22\% dengan hasil akhir rata-rata kelas pada siklus I sebesar 59\% dari sebelumnya $37 \%$ pada pra penelitian, sedangkan pada siklus II, persentase kenaikan sebesar 26\% dengan hasil akhir rata-rata kelas pada siklus II sebesar $85 \%$. Total kenaikan rata-rata kelas dari pra penelitian hingga akhir siklus II adalah sebesar 48\%. Hal ini memiliki makna bahwa telah terjadi peningkatan perilaku moral anak dari pra penelitian hingga akhir siklus II. Berdasarkan hal tersebut, maka dapat disimpulkan bahwa dalam proses pembelajaran anak usia dini hendaknya menerapkan metode dan media yang sesuai, memberikan motivasi dan contoh nyata yang tercermin dalam keseharian.

Kata Kunci : Perilaku moral, metode bercerita, penelitian tindakan

\section{PENDAHULUAN}

Manusia merupakan makhluk bermoral. Manusia dikatakan makhluk yang bermoral dan perilaku bermoral merupakan kodrat manusia karena pada dasarnya setiap manusia dilahirkan baik, memiliki kecenderungan untuk berbuat baik dan menyukai hal-hal yang baik (Mursidin 2011, 5). Perilaku moral tidak terlihat nyata, tetapi dapat dilihat dari ciri-cirinya secara fisik. Kecenderungan manusia untuk berbuat baik dapat dibuktikan dari ciri-ciri secara fisik yang dialami oleh manusia apabila melakukan hal-hal yang kurang baik, misalnya menyontek saat ujian, saat melakukan hal ini maka jantungnya akan berdebar kencang, mukanya memerah, perasaannya goyah, dan cara berbicaranya tidak terarah. Apabila perbuatan kurang baik ini telah menjadi kebiasaan, maka akan sulit untuk 
mengembalikannya menjadi perilaku baik sesuai kodratnya.

Moral merupakan kemampuan untuk belajar membedakan antara benar atau salah dan memahami cara untuk memilih di antaranya, pengertian ini sebagaimana dikutip dalam artikel Oswalth, 2017 "Morality is our ability to learn the difference between right and wrong and understand how to make the right choices". Jadi moral sangat berhubungan dengan benar salah, baik buruk, keyakinan, diri sendiri dan lingkungan sosial. Terdapat pedoman atau acuan agar manusia dapat membedakan antara baik dan buruk. Seseorang dianggap melakukan hal buruk, apabila melanggar aturan-aturan yang terdapat dalam pedoman tersebut. Begitupun sebaliknya, seseorang akan dianggap baik bila mengikuti aturan yang terdapat dalam pedoman. Pedoman tersebut adalah norma.

Setiap orang perlu memiliki perilaku moral yang baik agar dapat diterima di lingkungan masyarakat. Perilaku moral tidak serta merta menjadi karakter saat telah dewasa namun pembentukannya dimulai sejak usia dini. Anak pada dasarnya belum memahami perbuatan baik dan buruk, mereka belajar mengenai perbuatan baik dan buruk berdasarkan pengamatan dari berbagai variasi model yang ada dilingkungan terdekatnya, untuk itu anak perlu diberikan model yang tepat agar dapat melakukan perbuatan baik sesuai dengan aturan yang berlaku dalam lingkungan tempat anak berada. Perkembangan moral anak dipengaruhi oleh faktor internal dan eksternal. Anak belajar melalui lingkungannya, bagaimana seharusnya ia bersikap dan bertingkah laku. Lingkungan terdekat anak adalah keluarga dan sekolah. Di tempat inilah anak mendapatkan bimbingan untuk dapat berperilaku baik bersama dengan orangtua, guru, saudara dan teman sebaya.

Lembaga PAUD merupakan salah satu bagian yang dapat mempengaruhi perkembangan perilaku moral anak. Lingkungan ini memberikan kebebasan bagi anak untuk berinteraksi dengan orang dewasa dan teman sebayanya. Lembaga PAUD beserta sumber daya manusia yang terdapat didalamnya memiliki peranan penting dalam memberikan contoh dan pembiasaan berperilaku moral yang baik bagi anak dan menyelenggarakan kegiatan pembelajaran yang dapat meningkatkan perilaku moral baik anak. Perilaku moral baik anak dapat ditunjukkan dari bagaimana anak dapat berperilaku yang menunjukkan sopan santun, kepedulian, kejujuran, tanggungjawab dan taat pada peraturan yang berlaku.

Salah satu cara untuk mengembangkan perilaku moral yang baik adalah dengan metode bercerita. Melalui bercerita guru dapat menyampaikan ide, gagasan dan pesan moral bagi anak. Metode bercerita akan memberikan pengetahuan baru, memberikan contoh nilai baik dan buruk, benar dan salah, serta dapat menangkap pesan moral dan etika dalam cerita dengan cara yang menyenangkan pada anak.

Berdasarkan latar belakang di atas, maka dirumuskan masalah sebagai berikut: "Apakah perilaku moral anak usia 5-6 tahun di BKB PAUD Tunas Beringin dapat ditingkatkan melalui metode bercerita ?"

Secara umum, penelitian ini bertujuan untuk mengetahui apakah perilaku moral pada anak usia 5-6 tahun pada lembaga BKB PAUD Tunas Beringin dapat ditingkatkan melalui metode bercerita. Secara khusus, penelitian ini bertujuan untuk (1) mengetahui dan mendeskripsikan apakah perilaku moral anak usia 5-6 tahun dapat ditingkatkan melalui metode bercerita, (2) mengetahui dan mendeskripsikan cara mengembangkan perilaku moral anak usia 5-6 tahun melalui metode bercerita, dan (3) mengetahui dan mendeskripsikan seberapa besar perilaku moral anak usia 5-6 tahun dapat ditingkatkan melalui metode bercerita.

\section{KAJIAN LITERATUR}

\section{Perilaku Moral}


Pemahaman mengenai benar dan salah tergantung dari perkembangan anak secara kognitif. Hal ini sejalan dengan pendapat Piaget dalam Upton bahwa pemahaman tentang benar dan salah mencerminkan meningkatnya kecanggihan dalam proses-proses berpikir anak (Upton 2012, 177). Semakin berkembang tingkat keterampilan berfikir anak, anak akan semakin dapat membedakan antara benar dan salah serta alasan mengapa hal tersebut dikatakan benar atau salah.

Lickona berpendapat bahwa perilaku moral merupakan hasil dari pengetahuan moral dan perasaan moral. Pengetahuan dan perasaan moral ini yang kemudian diwujudkan dalam tindakan. Tahapannya adalah mengetahui hal yang baik, menginginkan hal yang baik, dan kemudian melakukan hal yang baik. Pengetahuan moral, perasaan moral dan perilaku moral tersebut saling mempengaruhi dan bersifat resiprokal (saling berbalasan). Pengetahuan moral dan perasaan moral mempengaruhi perilaku moral dan perilaku moral berpengaruh terhadap cara kita berfikir dan merasa.

Tahap perkembangan moral menurut Kohlberg adalah ukuran dari tinggi atau rendahnya moral seseorang berdasarkan penalaran moralnya (Sudarwan Danim dan Khairil 2010, 80). Penalaran moral memiliki hubungan yang positif dengan perkembangan moral anak, semakin tinggi penalaran moralnya maka semakin tinggi perkembangan moral dan sebaliknya semakin rendah penalaran moral, semakin rendah juga perkembangan moralnya. Kohlberg membagi tahap perkembangan moral menjadi 3 tingkat dan 6 tahap, yaitu : tingkat pra-konvensional, anak hanya mengetahui bahwa ia harus patuh terhadap aturan agar tidak mendapatkan hukuman; tingkat konvensional, anak mulai menyadari bahwa semakin baik perbuatan yang dilakukannya maka semakin banyak yang senang kepadanya, dan tingkat anu konvensional, anak mulai memahami aturan dan norma-norma yang ada di lingkungannya.
Perkembangan moral anak usia 5-6 tahun menurut kohlberg berada pada tahap prakonvensional, dimana anak memahami penilaian tentang baik atau buruk yang berdasarkan sistem hukuman dan penghargaan yang diawasi oleh orang dewasa yang berwenang. Pada tahap ini anak bertindak dan memberikan respons terhadap konsekwensi fisik dan tindakan anak dimotivasi oleh kepuasan atau kebutuhan.

Tahap penting dalam perkembangan moral anak menurut Bandura adalah Children actively construct standards of conduct - rules, goals, and expectations for their own conduct - through observing both themselves and other (Miller 2011, 249). Anak secara aktif membangun standard bersama baik aturan, tujuan dan harapan mereka sendiri berdasarkan pengamatan. Standar yang mereka bangun bersama tersebut akan membuat anak mematuhi aturan yang mereka sepakati bersama. Aturan, tujuan dan harapan tersebut kemudian dipantau oleh anak melalui hadiah dan hukuman yang mereka terima akibat dari kepatuhan dan ketidakpatuhan mereka terhadap aturan bersama. Hal senada disampaikan oleh Woolfolk yaitu terdapat tiga pengaruh penting terhadap perilaku moral menurut model, penghayatan, dan pembentukan konsep diri.

Berdasarkan uraian dari pendapat para ahli tersebut di atas, maka dapat disintesiskan bahwa perilaku moral anak usia 5-6 tahun adalah tindakan nyata yang dilakukan dalam melakukan hal yang benar berdasarkan sistem hukuman dan penghargaan sebagai refleksi dari interaksi terhadap lingkungan melalui proses pengamatan, peniruan dan pembiasaan.

\section{Metode Bercerita}

Salah satu upaya untuk mengembangkan perilaku moral yang baik pada anak usia dini adalah dengan metode bercerita. Melalui bercerita guru dapat menyampaikan ide, gagasan dan pesan moral bagi anak. Metode bercerita merupakan salah satu strategi pembelajaran yang diberikan oleh guru 
dalam menyampaikan materi pembelajaran dengan tujuan untuk memotivasi siswa mencapai tujuan pembelajaran dalam bentuk lisan untuk menyampaikan ilmu, pesan, nasihat kepada orang lain bedasarkan kejadian yang nyata maupun yang tidak nyata. Metode bercerita dapat disajikan dengan berbagai cara, bisa dengan media (alat bantu) atau tanpa media, bisa dengan buku cerita atau tanpa buku cerita.

Pada umur 5-7 tahun anak-anak mulai mengembangkan daya fantasinya, mereka sudah dapat menerima adanya benda atau binatang yang dapat berbicara. Sehingga tema cerita yang tepat untuk anak usia 5-6 tahun adalah cerita mengenai fabel atau cerita yang bertema mengenai kepahlawanan yang dikemas dalam cerita yang menyenangkan. Selain fabel dan cerita kepahlawanan, cerita rakyat adalah cerita yang paling cocok untuk didongengkan, karena bersifat fleksibel. Elemen-elemen yang ada dalam cerita dapat dihilangkan atau ditambahi sesuai dengan pendapat si pendongeng tentang bagian mana yang dirasa penting dan perlu ditonjolkan. Cerita rakyat merupakan cerita yang cocok untuk disampaikan kepada anak usia 5-6 tahun, karena mengandung banyak pesan moral dan dapat memberikan pengetahuan bagi anak mengenai keragaman adat istiadat dan budaya yang ada di Indonesia.

Persiapan yang diperlukan dalam menyajikan cerita adalah penyiapan tempat, penyiapan alat peraga dan persiapan dalam penyajian cerita (Tadkiroatun Musfiroh 2008, 119). Alat peraga atau media merupakan alat bantu yang penting dalam bercerita. Walaupun cerita dapat pula dilakukan secara lisan. media memiliki peranan untuk membantu mempercepat pemahaman terhadap cerita. Albert Meharabien menemukan peran media dalam menyampaikan informasi, dengan rumus tiga V. Verbal ; hanya bisa menyampaikan 7\%, Vocal; bisa mencapai $38 \%$ bila disertai dengan warna suara yang variatif dan intonasi yang tepat, sedangkan Visual; bisa mencapai angka keefektifan hingga mencapai 55\%
(Mursidin 2011 : 81-82). Dengan menggunakan media, pembawa cerita dapat menyampaikan informasi bukan hanya melalui verbal dan vocal, namun juga visual sehingga mengoptimalkan penyampaian pesan dari cerita.

Agar cerita menjadi lebih hidup dan menarik, maka pemberi cerita dapat mengoptimalkan unsur-unsur cerita seperti : dialog tokoh dan klimaks cerita, humor, peran serta pendengar, improvisasi, alat bantu dan olah suara (Tadkiroatun Musfiroh 2008, 150). Cerita dapat menjadi lebih hidup dan menarik bila pembawa cerita dapat menghidupkan tokoh dengan intonasi suara yang baik, memberikan selingan humor, menggunakan media, improvisasi dan mengajak pendengar untuk berpartisipasi serta membuat puncak cerita yang klimaks.

Perilaku yang dibawakan oleh tokoh dalam cerita dapat menjadi salah satu model pengamatan bagi anak, karena proses pembelajaran utama pada anak adalah melalui pengamatan. Anak memperhatikan tingkah laku model, kemudian menyimpannya, lalu melakukan proses imitasi yang berdasarkan motivasi yang dibangun dalam konsep diri anak. Bandura dalam pembelajaran sosial (Miller 2011, 234) mengatakan carried the concept of modeling one step further by demonstrating that relatively new behaviours can be acquired simply by watching a model who is reinforced. Anak dapat melakukan penguatan berdasarkan pengamatan terhadap perilaku tokoh-tokoh dalam cerita, kemudian anak mengkombinasikannya dalam proses kognitif dan melakukan peniruan perilaku sesuai dengan konsep yang menarik minatnya.

Metode bercerita tersebut kemudian dilanjutkan dengan guru melakukan pembiasaan berperilaku baik pada anak. Pembiasaan bukan hanya berlaku pada anak, tetapi guru memiliki peran penting sebagai model atau contoh nyata yang memiliki peluang besar ditiru oleh anak. Pemberian hadiah dan hukuman sebagai konsekuensi dari perbuatan baik dan 
buruk akan menguatkan konsep perilaku moral anak.

\section{METODE PENELITIAN}

Metode yang digunakan dalam penelitian ini adalah Penelitian Tindakan Kelas (PTK), dengan menggunakan model Kemmis \& McTaggart yang terdiri dari empat komponen, yaitu : perencanaan, tindakan, pengamatan dan refleksi dalam setiap siklusnya. Penelitian yang dilakukan sebanyak dua siklus, dimana pada tiap siklus difokuskan pada kegiatan dengan metode bercerita yang didalamnya mengandung pesan-pesan moral untuk berperilaku moral baik.

Penelitian tindakan dilaksanakan di BKB PAUD Tunas Beringin, yang berlokasi di Jalan Bunga Rampai I Rt. 01/010, Kelurahan Malaka Jaya, Kecamatan Duren Sawit, Jakarta Timur. BKB PAUD Tunas Beringin merupakan lembaga penyelenggara Pendidikan Anak Usia Dini pada jalur non formal dalam kategori SPS atau Satuan PAUD Sejenis yang terintegrasi dengan BKB dan salah satu lembaga binaan TPPKK Kelurahan Malaka Jaya. Subjek dalam penelitian ini adalah peserta didik dengan rentang usia 5-6 tahun yang berjumlah 10 anak, terdiri dari 6 anak laki-laki dan 4 anak perempuan. Partisipan dalam penelitian ini adalah guru kelas matahari yang berperan sebagai kolaborator yaitu guru yang melakukan proses pembelajaran di saat penelitian tindakan berlangsung.

Penelitian dilaksanakan pada tahun ajaran 2016-2017, yakni pada bulan November 2016 sampai dengan Juni 2017. Tahap awal penelitian dilakukan pengamatan mengenai perkembangan anak secara keseluruhan yang ada pada lembaga tersebut selama satu bulan. Setelah dilakukan observasi awal, peneliti menyusun dan membuat fokus penelitian, lalu dilanjutkan dengan penulisan proposal. Kegiatan tersebut dilakukan selama dua bulan yaitu bulan Januari sampai dengan Februari 2017. Pengambilan data dilakukan selama dua bulan yaitu bulan April sampai dengan bulan Mei 2017. Dilakukan sebanyak 3 kali dalam satu minggu. Selanjutnya dilakukan analis data selama dua bulan yaitu mulai akhir bulan Mei sampai dengan pertengahan Juli 2017, dan menyusunnya dalam bentuk laporan hasil penelitian.

Sumber data dalam penelitian ini adalah anak usia 5-6 tahun di BKB PAUD Tunas Beringin. Data yang dimaksud dalam penelitian ini dibagi menjadi 2 jenis yaitu data pemantau tindakan (action) dan data penelitian (research). Data pemantau tindakan digunakan sebagai pengontrol kesesuaian pelaksanaan tindakan dengan rencana yaitu kegiatan pembelajaran melalui metode bercerita. Adapun data penelitian (research) adalah data tentang variabel penelitian berupa perilaku moral anak usia 5-6 tahun. Data yang diperoleh digunakan untuk analisis data penelitian sehingga diperoleh gambaran adanya peningkatan perilaku moral anak.

Teknik pengumpulan data yang digunakan dalam melakukan penelitian adalah observasi, wawancara dan dokumentasi. Saat mengumpulkan data melalui observasi, peneliti memperoleh data dalam bentuk Catatan Lapangan (CL). Hal yang diamati fokus kepada perilaku dan tindakan moral anak. Teknik penilaian yang digunakan dalam catatan lapangan adalah running record dan time sampling.

Topik yang diajukan pada saat wawancara dalam penelitian adalah mengenai rutinitas anak, perilaku dan tindakan anak, stimulasi yang diberikan oleh guru dan orangtua, perasaan anak pada saat melakukan perilaku moral yang tidak baik. Pelakanaan wawancara dilakukan kepada guru, ketua lembaga, orangtua dan anak. Hasil wawancara dengan guru disingkat menjadi (CWG), dan wawancara dengan anak disingkat menjadi (CW). Teknik dokumentasi dilakukan dengan merekam gambar dan suara menggunakan kamera. Pengambilan dokumentasi ini disingkat dengan singkatan (CD). Dokumentasi yang direkam adalah perilaku anak pada saat melakukan kegiatan pembelajaran. 
Teknik analisis data dalam penelitian ini menggunakan analisis data kualitatif dan kuantitatif. Model Miles and Hubberman digunakan dalam analisis data kualitatif menggunakan catatan lapangan, catatan wawancara dan catatan dokumentasi, sehingga aktivitas yang dilakukan dalam menganalisis data adalah reduksi data, penyajian data, menarik kesimpulan dan verifikasi. Analisis data kuantitatif digunakan untuk mengetahui persentase peningkatan perilaku moral anak setelah tindakan menggunakan metode bercerita.

Adapun rumus yang digunakan untuk melihat adanya peningkatan perilaku moral tersebut, adalah sebagai berikut :

$$
\mathrm{P}=\quad \frac{\Sigma x}{N} \times 100 \%
$$

Keterangan :

P :Proporsi/perbandingan antara jumlah sampel dengan kemampuan yang dicapai oleh anak.

$\Sigma \mathrm{x}:$ Jumlah nilai/skor yang diperoleh anak

$\mathrm{N}$ :Nilai/skor maximal

\section{HASIL DAN PEMBAHASAN}

Tabel 8 persentase kenaikan pra penelitian

\begin{tabular}{|c|c|c|c|}
\hline Pra Penelitian & Siklus I & Siklus II & Peningkatan \\
\hline $37 \%$ & $59 \%$ & $85 \%$ & $48 \%$ \\
\hline
\end{tabular}

Intepretasi analisis data dijelaskan dalam dua jenis analisis data, yaitu analisis data kuantitatif dan analisis data kualitatif. Secara kuantitatif, sebagaimana telah di paparkan sebelumnya bahwa tingkat keberhasilan penelitian adalah hasil akhir rata-rata kelas sebesar $70 \%$. Berdasarkan hasil analisis data pada siklus I, persentase kenaikan sebesar 22\% dengan hasil akhir rata-rata kelas pada siklus I sebesar 59\%, sedangkan pada siklus II, persentase kenaikan sebesar 26\% dengan hasil akhir rata-rata kelas pada siklus II sebesar $85 \%$. Total kenaikan rata-rata kelas dari pra penelitian hingga akhir siklus II adalah sebesar $48 \%$. Hal ini memiliki makna bahwa telah terjadi peningkatan perilaku moral anak dari pra penelitian hingga akhir siklus II. Berikut adalah tabel dari peningkatan perilaku moral anak :

Analisis persentase kenaikan pra penelitian ke siklus II dihitung dengan rumus : Persentase siklus II - Persentase Pra Penelitian $=$ Peningkatan $=85 \%$ $37 \%=48 \%$

Peningkatan perilaku moral anak dari pra penelitian ke siklus II tersebut terlihat dalam grafik sebagai berikut :

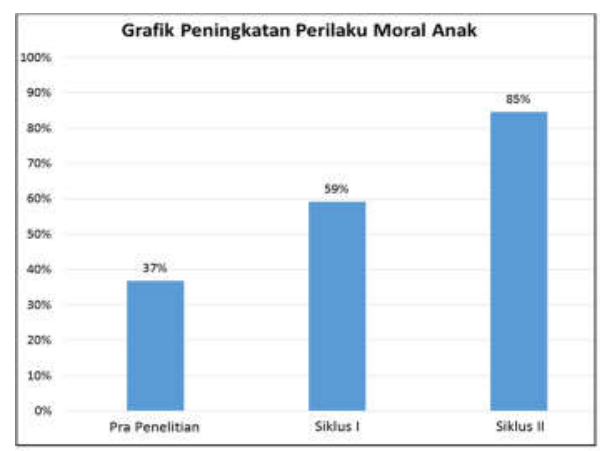

Bagan 1 Peningkatan perilaku moral anak dari pra penelitian

Hasil akhir pada siklus I sebesar 59\% belum mencapai tingkat keberhasilan yang diharapkan yaitu sebesar $70 \%$. Perilaku moral rata-rata anak usia 5-6 tahun di BKB PAUD Tunas Beringin belum mencapai indikator keberhasilan yang maksimal. Berdasarkan hal tersebut maka peneliti melakukan tindakan selanjutnya pada siklus II. Siklus lanjutan ini dimaksudkan untuk meningkatkan perilaku moral pada indikator yang masih rendah dan juga mempertahankan dan meningkatkan kembali indikator yang sudah terlihat mengalami peningkatan.

Pada akhir siklus II terlihat peningkatan yang lebih maksimal dibandingkan dengan siklus sebelumnya. Hasil akhir siklus II sebesar $85 \%$ dan hasil ini membuat tingkat keberhasilan maksimal telah tercapai, sehingga peneliti dan kolaborator memutuskan untuk menghendikan penelitian pada siklus II. Peningkatan perilaku moral anak mencakup indikator sopan santun, kepedulian, kejujuran, mematuhi aturan dan tanggung jawab.

Hasil analisis data kualitatif membuktikan bahwa penggunaan metode bercerita dapat meningkatkan 
perilaku moral anak. Melalui metode bercerita, anak terlihat lebih fokus dan antusias dalam kegiatan pembelajaran. Selain itu, anak juga dapat memahami isi cerita yang disampaikan dan memvisualisasikannya dengan mudah, sehingga pesan-pesan moral yang disampaikan oleh guru dapat diserap oleh anak. Guru juga dapat memberikan contoh mengenai perilaku moral baik pada anak melalui tokoh-tokoh yang diceritakannya.

Melalui metode bercerita anak juga diberikan materi dan kegiatan yang dapat mengembangkan perilaku moralnya. Materi yang di sampaikan dapat membuat anak membedakan perbuatan baik dan buruk berdasarkan contoh yang diberikan oleh guru, kemudian dilanjutkan dengan kegiatan yang membuat anak dapat menerapkannya dalam keseharian dengan bantuan penghargaan berupa pujian bagi anak yang berperilaku moral baik. Pembiasaan kemudian dilanjutkan hingga anak konsisten berperilaku moral baik. Pada akhir siklus II terlihat peningkatan perilaku moral baik pada anak. Sebagian besar anak telah terbiasa berperilaku moral baik dan sebagian lainnya berperilaku moral baik saat guru memberikan pujian.

Berdasarkan hasil penelitian mengenai peningkatan perilaku moral, dapat dilihat bahwa terdapat peningkatan perilaku moral anak usia 5-6 tahun di BKB PAUD Tunas Beringin. Peningkatan perilaku moral tersebut didukung oleh beberapa faktor hasil temuan peneliti saat melakukan tindakan dan pengamatan, yaitu : Guru dan peneliti melakukan kegiatan penyambutan kedatangan anak dan memastikan kondisi anak siap untuk menerima pembelajaran, mensosialisasikan peraturan kelas dibacakan setiap hari dan berulangulang, melakukan tanya jawab mengenai pesan-pesan moral yang disampaikan melalui cerita dapat membuat anak dapat membedakan perilaku baik dan buruk, pembiasaan dan pemberian contoh secara nyata dari guru dan peneliti dalam keseharian, dapat ditiru anak dan dijadikan contoh, memberikan pujian dan motivasi kepada anak menguatkan konsep anak dalam membedakan perbuatan baik dan buruk. Faktor-faktor tersebut dilakukan secara konsisten selama penelitian, sehingga anak terbiasa melakukannya. Proses peningkatan perilaku moral dimulai dari memahami, dapat membedakan, mulai berperilaku sesuai contoh hingga terbiasa didukung oleh motivasi dari guru dan peneliti berupa pujian dan reward.

Dalam penelitian terdapat 4 (empat) indikator perilaku moral baik yang dilakukan tindakan yaitu indikator sopan santun, kepedulian, kejujuran, mematuhi aturan dan tanggungjawab. Berikut adalah hasil temuan penelitian terkait dengan indikator tersebut :

1) Peningkatan tertinggi terlihat dari indikator mematuhi aturan yaitu dari sebesar $31 \%$ pada pra penelitian menjadi $89 \%$ pada akhir siklus II, sehingga terdapat kenaikan sebesar $58 \%$. Selain mengalami kenaikan tertinggi, indikator ini juga merupakan indikator rata-rata kelas tertinggi pada akhir siklus II.

2) Peningkatan terendah terlihat dari indikator kejujuran yaitu dari sebesar $47 \%$ pada pra penelitian menjadi $82 \%$ pada akhir siklus II, sehingga terdapat kenaikan sebesar $35 \%$. Meskipun indikator kejujuran merupakan indikator dengan peningkatan terendah namun indikator ini bukanlah indikator yang paling rendah pada akhir siklus II.

3) Peningkatan tertinggi perilaku moral secara keseluruhan adalah responden nomor 7 yaitu dari sebesar 33\% pada pra penelitian menjadi $86 \%$ pada akhir siklus II, sehingga terdapat kenaikan sebesar 53\%.

4) Perubahan sikap bukan hanya terlihat pada anak, namun juga terlihat pada guru. Guru yang menjadi model bagi anak, secara otomatis menunjukkan perilaku disiplin dan mematuhi aturan yang telah disepakati.

Hasil secara kualitatif menunjukkan bahwa metode bercerita dapat 
meningkatkan perilaku moral anak. Merujuk pada teori tahap penting perkembangan moral anak yang dikemukakan oleh Bandura yaitu Children actively construct standards of conduct - rules, goals, and expectations for their own conduct - through observing both themselves and other, temuan hasil penelitian membuktikan bahwa perilaku moral anak dapat ditingkatkan dengan membuat kesepakatan bersama antara peneliti, guru dan anak. Kesepakatan tersebut kemudian di terapkan dalam pembiasaan di kegiatan sehari-hari. Peneliti dan Guru sebagai model memberikan contoh perilaku baik yang kemudian ditiru oleh anak. Peneliti dan guru juga memantau perilaku moral baik anak melalui hadiah dan hukuman yang diterima oleh anak sebagai akibat dari kepatuhan dan pelanggaran terhadap aturan yang telah disepakati.

Anak dapat membedakan perilaku moral baik dan buruk melalui metode cerita, karena dalam bercerita di sampaikan pesan-pesan moral dengan cara yang menyenangkan. Peneliti kemudian memberikan contoh dan pembiasaan serta memberikan pujian bagi anak yang berperilaku baik. Dengan demikian anak dapat menerapkan dalam kegiatan sehari-hari dan terbiasa berperilaku moral baik.

Berdasarkan hasil analisis data kuantitatif diperoleh persentase peningkatan perilaku moral pada akhir siklus I sebesar 59\% dan $85 \%$ pada akhir siklus II, karena itu peneliti dan kolaborator memutuskan untuk menghentikan penelitian karena tingkat keberhasilan telah tercapai pada siklus II. Hasil tersebut menunjukkan kesesuaian dengan hipotesis tindakan yaitu dengan menggunakan persentase minimun sebesar $70 \%$ maka hipotesis diterima. Dengan demikian hipotesis tindakan yang menyatakan bahwa perilaku moral anak usia 5-6 tahun dapat ditingkatkan melalui metode bercerita, diterima.

\section{KESIMPULAN}

Berdasarkan hasil penelitian terhadap pelaksanaan tindakan pada siklus I dan siklus II, dapat diambil kesimpulan bahwa perilaku moral anak usia 5-6 tahun pada BKB PAUD Tunas Beringin dapat ditingkatkan melalui metode bercerita.

Penelitian ini memberikan suatu gambaran jelas bahwa keberhasilan tindakan dalam meningkatkan perilaku moral anak tergantung pada beberapa faktor. Faktor-faktor tersebut berasal dari guru, anak, media dan alat pembelajaran serta metode pembelajaran yang digunakan. Pencapaian tingkat keberhasilan yang optimal di sebabkan karena kemampuan guru dalam mengembangkan cerita, membuat cerita lebih menarik dengan intonasi suara dan berbagai ekspresi, dan kemampuan guru dalam mengelola kelas. Situasi yang menyenangkan membuat anak menjadi lebih antusias dan tertarik untuk berpartisipasi aktif dalam kegiatan pembelajaran.

Penggunaan metode bercerita membuat anak mengetahui dan memahami perbedaan antara perilaku moral baik dan buruk. Anak menggabungkan pengalaman yang dimilikinya dengan pengetahuan yang baru saja didapatkannya. Guru kemudian membantu anak dengan menjadi contoh menerapkan perilaku moral baik ke dalam kegiatan sehari-hari, anak yang merupakan peniru yang ulung kemudian melakukan hal yang dicontohkan oleh guru, melalui pembiasaan dan pujian yang diberikan kepada anak, anak perlahan dapat menerapkan perilaku moral baik dalam keseharian.

Penggunaan metode ini juga berdampak positif terhadap perubahan sikap guru. Guru yang sebelumnya belum menerapkan kedisiplinan dan perilaku moral baik berdasarkan hasil observasi peneliti pada pra penelitian, kemudian menjadi disiplin baik saat kedatangan maupun dalam kegiatan di dalam kelas. Guru mempersiapkan media dan mengkondisikan kelas sebelum memulai kegiatan. Guru yang merupakan contoh dari anak, menunjukkan perubahan sikap yang positif, karena anak selalu melakukan pengamatan 
terhadap perilaku yang ditunjukkan oleh guru.

Penelitian ini juga memberikan deskripsi yang jelas bahwa penggunaan metode bercerita dapat meningkatkan perilaku moral anak usia 5-6 tahun pada BKB PAUD Tunas Beringin. Penelitian ini dapat digunakan sebagai suatu pertimbangan bagi guru yang ingin meningkatkan perilaku moral anak khususnya usia 5-6 tahun, karena metode bercerita merupakan metode yang menarik dan menyenangkan bagi anak. Bagi guru metode bercerita mempermudah pemahaman kepada anak dalam menyampaikan pesan-pesan moral yang baik.

\section{REFERENSI}

Danim, Sudarwan dan Khairil. 2010. Psikologi Pendidikan. Bandung : Alfabeta.
Musfiroh, Tadkiroatun. 2008. Cerita untuk anak usia dini. Yogyakarta : Tiara Wacana.

Mursidin. Moral sumber pendidikan. 2011. Bogor: Ghalia Indonesia.

Miller, Patricia. H. 2011. Theories of Developmental Psycology Fifth Edition. New York : Worth Publisher.

Upton, Penney. 2012. Psikologi Perkembangan terjemahan Noermalasari Fajar Widuri. Jakarta : Erlangga.

Oswalt, Angela. Early Chidhood Moral Development.

(http://gracepointwellness.org) Diunduh tanggal 30 Januari 2017, pkl. 21.34 